\title{
Genetic evaluation of the functional productive life in Slovak Simmental cattle
}

\author{
Eva Strapáková', Juraj Candrák1, Peter Strapák² and Anna Trakovická' \\ 'Department of Genetics and Breeding Biology, ${ }^{2}$ Department of Animal Husbandry, Faculty of Agrobiology and Food \\ Resources, Slovak University of Agriculture in Nitra, Nitra, Slovak Republic
}

\begin{abstract}
Genetic evaluation of sires based on length of functional productive life of their daughters was carried out using a Weibull proportional hazard sire-maternal grandsire model. The data consisted of 214634 registered Slovak Simmental cows with censoring of $21.34 \%$. Besides the random sire and maternal grandsire effects, the model included time dependent effects of parity xstage of lactation interaction, within-herd standard deviations of milk production, herdxyearxseason interaction, change of herd size with respect to the previous year and time independent effect age at first calving. Within-herd, the standard deviations of milk production had the most important influence on functional productive life. The highest risk of culling was found in cows with the lowest milk production class (uncompleted lactation). Risk of culling decreased with an increasing milk production class. Estimated heritability of functional productive life was 0.05 on the original scale. Breeding values of sires expressed as a risk ratio of their daughters were between -0.57 and 0.53 .
\end{abstract}

Keywords: dairy cattle, genetic evaluation, functional productive life, survival analysis

Abbreviations: HSP: heat shock protein, RBV: relative breeding values, SD: standard deviation

\section{Introduction}

The Slovak Simmental cattle is a dual purpose breed specialized mainly in milk production. Current population include 30150 cows, 39053 heifers and 911 Simmental bulls. Average milk yield is about $5640 \mathrm{~kg}$ and number of completed lactations is 2.51 (Herd Book of Slovak Simmental Breed).

Archiv Tierzucht 56 (2013) 79, 797-807

doi: 10.7482/0003-9438-56-079

Corresponding author:

Eva Strapáková; email: eva.strapakova@uniag.sk

KGPB FAPZ SPU v Nitre, Tr. A. Hlinku 2, 94976 Nitra, Slovak Republic
Received: 20 November 2012

Accepted: 18 June 2013

Online: 18 June 2013

(c) 2013 by the authors; licensee Leibniz Institute for Farm Animal Biology (FBN), Dummerstorf, Germany. This is an Open Access article distributed under the terms and conditions of the Creative Commons Attribution 3.0 License (http://creativecommons.org/licenses/by/3.0/). 
From 2008, Slovakia is the 28th member participating in the routine genetic evaluation of milk yields of Slovak Simmental and Holstein breeds (Candrák \& Ryba 2009).

Besides production traits, productive life, fertility and type traits have a great impact on efficiency and profitability of dairy industry (Páchová \& Dědková 2003). Longer productive life leads to a decrease of replacement costs and higher proportion of cows that are in later, high producing lactations (Vukasinovic et al. 1997).

Productive life is defined as the number of days from first calving until culling and is dependent on level of production. Functional productive life, presented by Ducrocq (1994), reflects the ability of cows to delay involuntary culling because of e.g. udder disorders, infertility or reproductive disorders, lameness or foot and leg defects, emergency culling reasons and other health disorders. For distinguish voluntary and involuntary culling, level of production is added to the model. Therefore estimated breeding values for longevity include only involuntary culling (van der Linde et al. 2007).

The major problem with selecting for longevity is an absence of complete length of productive life (censored data) in live cows at the end of the study period. Further, the distribution of survival time is seldom known and in most cases extremely skewed (Sölkner \& Ducrocq 1999).

The implementation of survival analysis in genetic evaluation allowed us to process censored as well as uncensored data, time-dependent covariates and random covariates (Ducrocq 1994, Vukasinovic et al. 1997, Forabosco et al. 2006). The Weibull proportional hazard model is a well-known method of survival analysis, which can therefore be used for estimation of breeding values of functional productive life. This model is based on a hazard rate which defines probability of being culled at time $t$, given that a cow is still alive immediately prior to $t$. The hazard rate is described as a product baseline hazard function, representing the aging process and function of explanatory variables affecting culling rate of cows (Caraviello et al. 2004).

A further problem with the evaluation of productive life is the low heritability. Páchová et al. (2005), van der Linde et al. (2007), Bonetti et al. (2009), Vukasinovic et al. (1997), M'hamdi et al. (2010) and Mirtaghizadeh (2004) reported on a heritability value between 0.018 to 0.19 . Tekerli \& Koçak (2009) computed heritability for length of productive life of Holstein cows 0.29 using linear mixed model least squares and maximum likelihood program of Harvey's. It appears that culling is heavily influenced by herd management practices.

Parity and stage of lactation, herd, year and season of calving, within-herd class effect of milk production, variation in herd size and sire genetic effect were confirmed as factors influencing the length of productive life by Ducrocq (1994), Caraviello et al. (2004), Mészáros et al. (2008) and Bonetti et al. (2009). The age of first calving has smaller influence on length of productive life by Ducrocq (1994), Vukasinovic et al. (1997) and Strapák et al. (2010).

Sawa \& Bogucki (2010) reported that lifespan and length of productive life is highest in herds of up to 20 cows, in herds with the lowest production level, in herds of cows that calved the first time before 24 months of age, and in herds of cows that yielded $4000-7000 \mathrm{~kg}$ milk as first calvers.

Other factors influencing the length of productive life are stress factors that are under genetic control such as heat shock protein (HSP) loci. They could be potential candidate genes for stress susceptibility. In the bovine hsp70.1 gene a functional AP2 box variant is affecting a 
significant decrease of cellular stress response (Schwerin et al. 2003). Authors suggested that animals with higher stress tolerance reached longer productive life.

The aim of this study was the estimation of the influence of chosen fixed and random effects on length of productive life and the estimation of genetic effects and heritability. Further, breeding values of sires based on length of functional productive life of their daughters were estimated.

\section{Material and methods}

The data were provided by the Slovak Breeding Services and the Breeding Book of Slovak Simmental Breed. The data consist of records of the productive life of 214634 registered cows with the first calving between 1992 and 2009 belonging to 1493 herds in the Slovak Republic.

The length of functional productive life was calculated as the number of days from the first calving until culling or censoring. Animals with unknown sire and culling day, with more than 10 lactations and those sold for other purpose were considered as censored.

The statistical software SAS 9.2 (SAS Institute Inc., Cary, NC, USA) and the application Enterprise Guide 4.2 (SAS 2008) were used for preparation of databases. The Survival Kit v6.0 (Ducrocq et al. 2010) was used for the estimate of breeding values for length of functional productive life.

The analysis was carried out using a Weibull proportional hazard sire-maternal grandsire model. The following effects were included in the model:

$$
\lambda(t)=\lambda_{0}(t) \exp (p / s+m+h s+a g e+h y s+s+0.5 \mathrm{mgs})
$$

where $\lambda(t)$ is the hazard function (instantaneous probability of culling) for a given cow at time $t, \lambda_{0}(t)$ is the Weibull baseline hazard function, pls is the fixed time-dependent effect of the parity $\times$ stage of lactation interaction. Parity had 10 classes (1-10+) and the stage of lactation involved 3 classes - 1: from 1 to 100 days, 2: from 101 to 200 days and 3: more than 201 days including a dry period. Variable $m$ is the fixed time-dependent effect of the milk production class, expressed as a standard deviation (SD) from within-herd-year average (6 classes with changes after each calving, 1: $<-2$ SD, 2: -2 SD to $<-1$ SD, 3:-1 SD to<herd-year average, 4: herd-year average to<+1 SD, 5: +1 SD to<=+2 SD from herd-year average, 6: $>+2$ SD), hs is the fixed time-dependent effect of the variation of herd size was expressed as increase $(+)$ or decrease $(-)$ number of cows in comparison with last year (6 classes $-1:<-75 \%, 2$ : $-75 \%$ to $<-25 \%, 3:-25 \%$ to $<0 \%, 4: 0 \%$ to $<+25 \%, 5:+25 \%$ to $<+75 \%, 6: \geq+75 \%$ ), age is the fixed time-independent effect of the age at first calving with 5 classes - 1: age from 600 to 778 days, 2: age from 779 to 892 days, 3: age from 893 to 1000 days, 4: age from 1001 to 1200 days, 5: age from 1200 to 1500 days, hys is the random time-dependent effect of the herd $\times$ year $\times$ season interaction, following a log-gamma distribution with change points at April 1 and October 1 in each calendar year $(n=25751), s$ is the time independent random effect of the sire of the cow, assuming to follow a multivariate normal distribution. Pedigree included 1626 sires and the total bull number in the pedigree was $5225.0 .5 \mathrm{mgs}$ is the random effect of maternal grandsire. 
A Likelihood Ratio Test was used to check the importance of the factors influencing the length of the functional productive life of cows.

The proportion measure of the model explained variation was calculated according to Maddala (1983):

$$
R_{M}^{2}=1-\left(\frac{L_{R}}{L_{U}}\right)^{\frac{2}{n}}
$$

where $n$ is the total sample size, $L_{R}$ is the restricted maximum likelihoods and $L_{U}$ is the unrestricted maximum likelihoods.

The influence of the fixed factors was expressed as a relative culling rate, which is defined as the ratio between the estimated risk of culling and mean risk setting to 1 . For fixed effects that are time dependent the level with the highest uncensored records was assumed to be the average risk. This level was used for comparison with all other levels of the effect (Vukasinovic et al. 1997).

The heritability was calculated according to Yazdi et al. (2002):

$$
h^{2}=\frac{4 \sigma_{s}^{2}}{\sigma_{s}^{2}+\sigma_{\text {hys }}^{2}+\frac{1}{p}}
$$

where $\sigma_{s}^{2}$ is the sires variance, $\sigma_{\text {hys }}^{2}$ is the herd $\times$ yearx $\times$ season interaction variance and $p$ is the proportion of culled cows.

The breeding value for functional productive life was expressed as a relative breeding value with an average of 100 and genetic standard deviation of 12. Reliabilities were computed following Ducrocq (2005) as:

$$
R^{2}=\frac{N h^{2}}{(N-1) h^{2}+4}
$$

where $N$ is the number of all sire's daughters and $h^{2}$ is the heritability.

\section{Results and discussion}

All data contain $21.34 \%$ censored information. The average length of functional productive life in the analysed group of 214634 Slovak Simmental cows reached 1166 days for censored and 1084 days for uncensored records (Table 1) which is comparable with Řehout \& Polenská (1990). Strapák et al. (2008) stated a longer productive life of culled Slovak Simmental cows of an average of +327 days, which was computed using a linear model.

Table 1

The length of functional productive life of Slovak Simmental cows for uncensored and censored records

\begin{tabular}{lcc}
\hline Functional productive life, days & Uncensored records & Censored records \\
& $\mathrm{n}=168822(78.66 \%)$ & $\mathrm{n}=45812(21.34 \%)$ \\
\hline Mean & 1084 & 1166 \\
Minimum & 3 & 2 \\
Maximum & 4713 & 4970 \\
\hline
\end{tabular}


The baseline hazard function shows the risk of culling at a time $t$ for all cows in the analysis and depends on the age of a cow (Figure 1). The risk of culling increases when the cows get older.

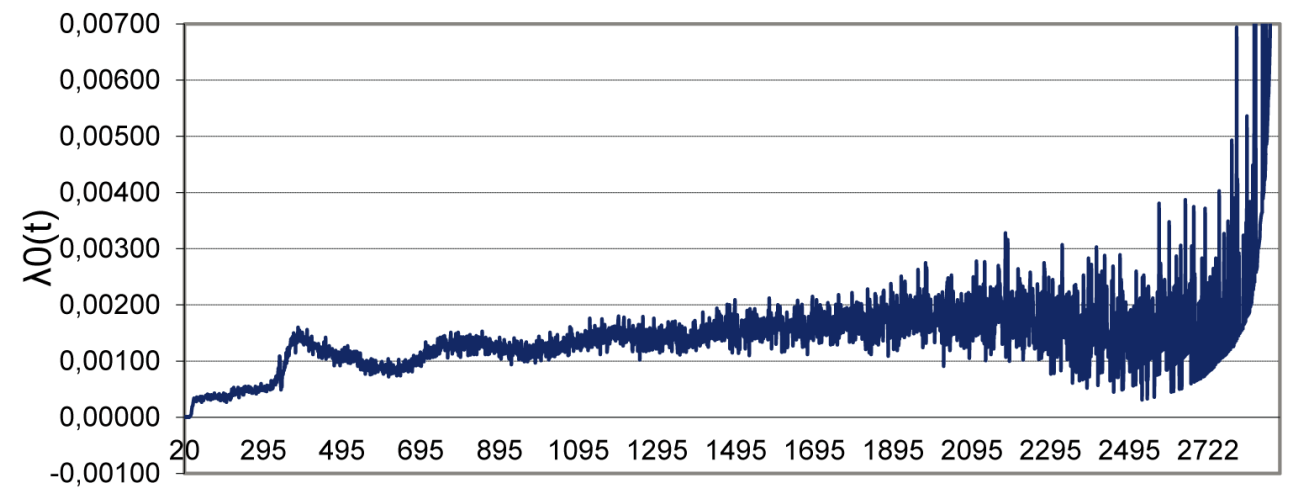

\section{Productive life (days)}

Figure 1

Baseline hazard function for all cows in the analysis

The influence of the fixed factors on length of functional productive life

Table 2 shows the results of the likelihood ratio test. All effects were significant. The two most important factors were milk production class and parity $\times$ stage of lactation interaction. Very small changes in log likelihood were observed after the effect of age at first calving was included in the comparison with the other effects. Reliability $\left(\mathrm{R}^{2}\right)$ according to Maddala (1983) reached 0.67.

Table 2

The influence of the factors on length of functional productive life

\begin{tabular}{lcc}
\hline Effects & -2 Change in log likelihood & $\mathrm{R}^{2}$ by Maddala \\
\hline sire & 9286.6 & - \\
sire, mgs & 386.35 & 0.04 \\
sire, mgs, pls & 21804 & 0.13 \\
sire, mgs, pls, m & 143420 & 0.55 \\
sire, mgs, pls, m, hys & 61215 & - \\
sire, mgs, pls, m, hys, age & 283.73 & 0.66 \\
sire, mgs, pls, m, hys, age, hs & 3701 & 0.67 \\
\hline
\end{tabular}

mgs: effect of maternal grandsire, pls: effect of parity $\times$ stage of lactation interaction, m: effect of milk production classes, hys: effect of herd $\times y$ year $\times$ season interaction, age: effect of age at first calving, hs: effect of variation of herd size

Effect of milk production classes on the risk ratio

The cows with low production were at higher risk of culling than cows producing average to +1.0 SD (class 4) (Table 3). The risk ratio decreased with increasing production levels. Sawa \& Bogucki (2010) reported that productive life increases the most expressively (about 0.5 of year) in herds with an average first lactation milk yield of 4000 to $7000 \mathrm{~kg}$. 
Table 3

Estimates of relative risk ratios for milk production classes (expressed as SD from within-herd-year average)

\begin{tabular}{lccc}
\hline Class & Lower bound (SD) & Upper bound (SD) & Risk ratio \\
\hline 1 & & $<-2.0$ & 1.124 \\
2 & -2.0 & $<-1.0$ & 1.071 \\
3 & -1.0 & $<0$ & 1.024 \\
4 & 0 & $<+1.0$ & 1.000 \\
5 & +1.0 & $\leq+2.0$ & 0.990 \\
6 & $>+2.0$ & & 0.987 \\
\hline
\end{tabular}

Chirinos et al. (2007) calculated a 2.38 times higher risk ratio for cows with milk production deviations lower than $-30 \%$ in comparison with cows, that reached the average milk production. On the contrary, in cows with a deviation higher than $+30 \%$ the risk ratio was 1.13 times lower. Mészáros et al. (2008) state a similar risk ratio tendency in Slovak Pinzgau cattle with highest calculated risk ratio (5.27) in the class of cows producing less than -1.5 standard deviation from average production of the herd.

Effect of the parity $\times$ stage of lactation interaction on the risk ratio In this paper 10 lactations were evaluated, each with 3 stages of lactation. The risk ratio was estimated only for 9 lactations, because there was no uncensored record for the 10th lactation.

The results of analysis confirmed more intensive selection in the third stage of lactation mainly at the dry period, when the risk ratio increased (Table 4).

Table 4

Estimates of relative risk ratios for classes of the parity $\times$ stage of lactation interaction

\begin{tabular}{lccc}
\hline Lactation & to 100 days & $\begin{array}{c}\text { Stage of lactation } \\
101 \text { to } 200 \text { days }\end{array}$ & $\begin{array}{c}\text { more than 201 days including } \\
\text { a dry period }\end{array}$ \\
\hline 1 & 0.631 & 0.610 & 1.000 \\
2 & 0.214 & 0.374 & 0.891 \\
3 & 0.207 & 0.372 & 0.905 \\
4 & 0.221 & 0.385 & 0.943 \\
5 & 0.240 & 0.417 & 1.000 \\
6 & 0.272 & 0.424 & 1.028 \\
7 & 0.288 & 0.464 & 1.048 \\
8 & 0.287 & 0.482 & 1.184 \\
9 & 0.289 & 0.485 & 1.221 \\
\hline
\end{tabular}

The cows at the end of the first lactation showed 1.58 times higher risk of culling in comparison with the cows at the 100th day of lactation. The trend of the risk ratio was similar at 2 nd up to 7 th lactation. The risk ratio decreased with each other lactation. M'hamdi et al. (2010) and Vukasinovic et al. (1997) confirmed that more intensive culling of cows occurred at the end of lactations. Raguž et al. (2011) acknowledged that the animals from lower parities had higher risks of culling resulting in about 14 times higher in Simmental Breed in Croatia. The influence of factor parity $\times$ stage of lactation interaction analysed also by Mészáros et al. (2008), they acknowledged a 4.14 times higher risk of culling at 180th day of the first lactation 
in comparison to the cows at the end of lactation whereby the risk ratio decreased, excepting the second lactation and the end of each lactation.

Effect of the variation in herd size on the risk ratio

The variation in herd size was calculated as a percentage increase or decrease of the number of the cows in herd in comparison with previous year. The variation size of the herd from 0 to $+25 \%$ was set as a reference class (Table 5 ).

Table 5

Estimates of relative risk ratios for classes of the variation in herd size

\begin{tabular}{lccc}
\hline Class & Lower bound & Upper bound & Risk ratio \\
\hline 1 & & $<-75 \%$ & 1.540 \\
2 & $-75 \%$ & $<-25 \%$ & 1.160 \\
3 & $-25 \%$ & $<0$ & 1.349 \\
4 & 0 & $<+25 \%$ & 1.000 \\
5 & $25 \%$ & $<75 \%$ & 0.821 \\
6 & $>75 \%$ & & 0.515 \\
\hline
\end{tabular}

The highest risk ratio was reached in the cows in the herds with a decrease of the herd size more than $-75 \%$ (1.54 times higher than in the reference class). Vice versa, the risk of being culled descended to 0.515 in the sixth class.

Increasing herds showed decreasing risk ratio which was confirmed also by other authors (Mészáros et al. 2008, Chirinos et al. 2007). Similar tendency was showed by Terawaki et al. (2006) and Pasman \& Reinhardt (1999).

Effect of the age at first calving on the risk ratio

The age at first calving had a smaller, but significant effect on the length of functional productive life. In comparison with other factors, risk ratio showed considerably lower variability (from 0.953 to 1.124) (Table 6), which was confirmed also by papers from Raguž et al. (2011) and Mészáros et al. (2008). The authors showed that the risk ratio of the age at first calving was in the range from 0.927 to 1.025 and from 1.05 to 1.19 , respectively.

Table 6

Estimates of relative risk ratios for classes of the age at first calving

\begin{tabular}{lccc}
\hline Class & $\begin{array}{c}\text { Lower bound } \\
\text { (days) }\end{array}$ & Upper bound & $\begin{array}{c}\text { Risk ratio } \\
\text { (days) }\end{array}$ \\
\hline 1 & 600 & 778 & 0.953 \\
2 & 779 & 892 & 1.000 \\
3 & 893 & 1000 & 1.052 \\
4 & 1001 & 1200 & 1.056 \\
5 & 1201 & 1500 & 1.124 \\
\hline
\end{tabular}

The reference class was given the age at first calving between 779 and 892 days (Table 6). The cows of Slovak Simmental breed with an age at first calving between 600-778 days reached about 1.05 times lower risk ratio in comparison to reference class. The cows calving with a higher age achieved shorter production life. 


\section{Genetic parameters and heritability}

Genetic parameters were estimated from the base of 1122 sires, having a minimum of 10 daughters in analysis. The genetic variance of sires $(0.02)$ and variance of herd $\times$ year $\times$ season factor (0.17) were included to calculate heritability, resulting in a value $h^{2}=0.05$. Mészáros et al. (2008) reported on the identical coefficient of heritability in Pinzgau Cattle in the Slovak Republic, Potočnik et al. (2009) presented a heritability of 0.06 for Simmental in Slovenia. Higher values of heritability were estimated by identical method in Simmental population-in Austria, Germany $\left(h^{2}=0.12\right)$ and the Czech Republic $\left(h^{2}=0.23\right)$ (Interbull 2003). Vukasinovic et al. (2001) and Bonetti et al. (2009) stated heritability values of 0.19 for Simmental and 0.12 for Italian Brown Swiss, respectively.

\section{Breeding values}

Estimated breeding values of all bulls in pedigree ranged from -0.57 to 0.53 , corresponding with relative risk ratios between 0.56 and 1.7. Negative values represent longer productive life of cows. Relative breeding values (RBV) of sires ranged from 44.8 to 165.6 , values more than 100 express longer productive life of cows. These cows have less risk to be culled.

The reliability of breeding value estimation $\left(R^{2}\right)$ depends on the total number of daughters; the higher number of daughters and the higher reliability. The average reliability of 0.34 was achieved from bulls with 42 daughters. The maximum value was 0.98 (bull with 5975 daughters). Mészáros et al. (2008) found out reliability with a mean of 0.25 and the maximum value was 0.96 . The average reliability was reached for bulls with 27 uncensored daughters.

Table 7 shows RBV of top ten sires of Slovak Simmental cows. The highest breeding value of 165.6 with a reliability of 0.97 was reached by Egos-ET, bulls of Slovak origin. Following bulls were Maigold ( $\left.R B V=164.4, R^{2}=0.89\right)$ of German origin and $G S$ Dionis ( $R B V=158.7, R^{2}=0.93$ ) of Austria origin (Table 7).

Table 7

Relative breeding values for functional productive life of top 10 sires of Slovak Simmental cattle

\begin{tabular}{lccccc}
\hline Sire & Country of origin & National register of bull & No of daughters & RBV & Reliability of RBV \\
\hline Egos-ET & Slovakia & 003 & 3533 & 165.6 & 0.97 \\
Maigold & Germany & 011 & 693 & 164.4 & 0.89 \\
GS Dionis & Austria & 005 & 1228 & 158.7 & 0.93 \\
Hippo & Germany & 004 & 1186 & 145.1 & 0.93 \\
Epo & Germany & 010 & 488 & 140.9 & 0.86 \\
Ress & Austria & 001 & 2498 & 140.7 & 0.96 \\
Arktida & Czechia & 017 & 44 & 139.5 & 0.35 \\
Aimant & Czechia & 001 & 508 & 139.1 & 0.86 \\
Sauerbruch & Germany & 007 & 182 & 138.7 & 0.69 \\
Paramos & Slovakia & 101 & 40 & 135.2 & 0.33 \\
\hline
\end{tabular}

Relative breeding values with a reliability of more than 0.30 were published. Vukasinovic et al. (2001) published breeding values with a reliability of at least 0.50 in the first national genetic evaluation. In other countries, breeding values are published variously in the international genetic evaluation (Austria - if breeding value for milk yield is official, all other breeding values are official, if not so, minimum reliability is 0.30 ; France and Switzerland - reliability is more than 0.50$)$ (www1). 
The genetic trend of RBV for functional productive life indicates an evolution in breeding of Slovak Simmental cows (Figure 2).

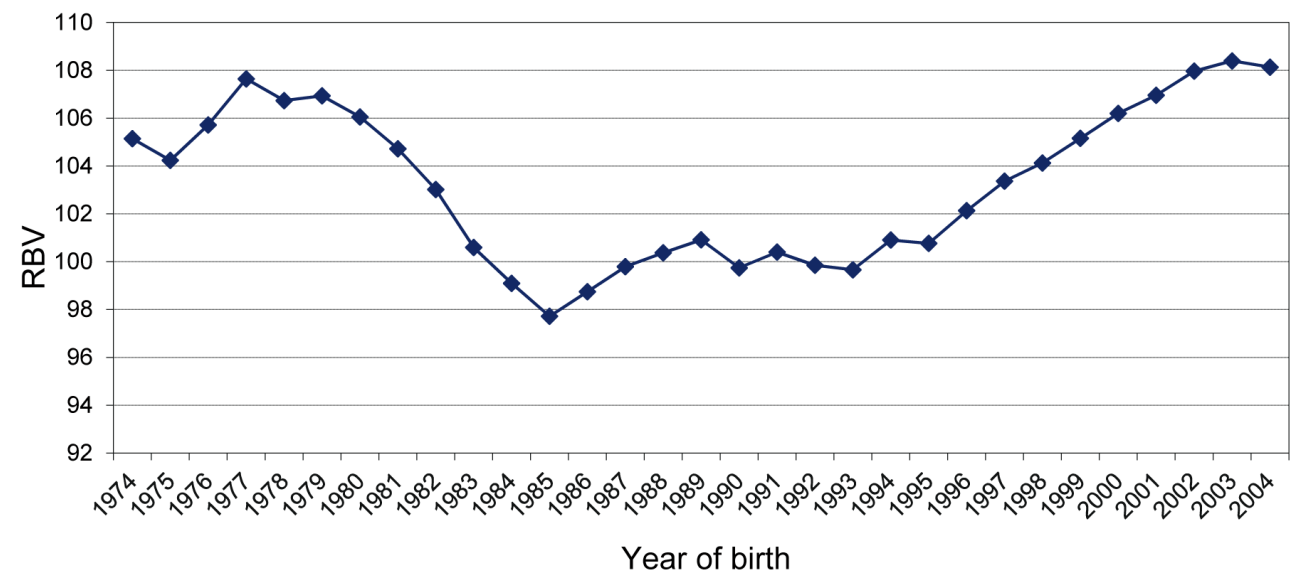

Figure 2

Genetic trend estimates of the functional productive life relative breeding values (running averages of 4 years)

The decreasing trend was felt in the seventies and half of the eighties. Probably it was a demonstration of the effect of crossbreeding with Holstein breed, which was focused on the increase of milk production. The increase of the RBV in the early nineties may have been caused by the import of the Simmental bull sperm from abroad, where these bulls were selected also for longevity.

Current crossbreeding situation is focused on purebred breeding in Slovak Simmental cattle. In conclusion, the genetic evaluation for functional productive life has been performed for the first time for Slovak Simmental cattle in Slovakia. Published breeding values help farmers to eliminate sires with low breeding value for longevity and so to prevent a decrease of productive life in the population.

Currently, this method is prepared for the implementation of routine genetic evaluation of Slovak Simmental and Holstein breeds longevity. All factors, which were used in this study, are included also in the model, however with minor changes (e.g. age at first calving between 600-1 200 days).

Breeding values for longevity will be added to newly-formed total merit index in Slovakia.

\section{Acknowledgements}

Financial support was provided by the project APVV-0636-11 and KEGA 027SPU-4/2012. I would like to express my very great appreciation to Tatiana Simkova, Aptos, California for spell checking of this paper.

\section{References}

Bonetti O, Rossoni A, Nicoletti C (2009) Genetic parameters estimation and genetic evaluation for longevity in Italian Brown Swiss bulls. Ital J Anim Sci 8 (Suppl.), 30-32 
Candrák J, Ryba Š (2009) [Slovak Republic became part of international genetic evaluation Interbull. Historic step and success]. Slovenský chov 4, 25-26 [in Slovak]

Caraviello DZ, Weigel KA, Gianola D (2004) Prediction of Longevity Breeding Values for US Holstein Sires Using Survival Analysis Methodology. J Dairy Sci 87, 3518-3525

Chirinos Z, Carabaño MJ, Hernández D (2007) Genetic evaluation of length of productive life in the Spanish Holstein-Friesian population. Model validation and genetic parameters estimation. Livest Sci 106, 120-131

Ducrocq V (1994) Statistical Analysis of Length of Productive Life for Dairy Cows of the Normande Breed. J Dairy Sci 77, 855-866

Ducrocq V (2005) An improved model for the French genetic evaluation of dairy bulls on length of productive life of their daughters. Anim Sci 80, 249-256

Ducrocq V, Sölkner J, Mészáros G (2010) The Survival Kit v6.0. User's Manual

Forabosco F, Bozzi R, Filippini F, Boettcher P, van Arendonk JAM, Bijma P (2006) Linear model vs. survival analysis for genetic evaluation of sires for longevity in Chianina beef cattle. Livest Sci 101, 191-198

Herd Book of Slovak Simmental Breed, version 5.0

Interbull (2003) Description of national genetic evaluation systems for dairy cattle traits as practised in different Interbull member countries. http://www-interbull.slu.se/national_ges_info2/framesida-ges. htm [last accessed 3.9.2012]

Maddala GS (1983) Limited-dependent and qualtitative variables in econometrics. Cambridge University Press, Cambridge, UK

Mészáros G, Fuerst C, Fuerst-Waltl B, Kadlečík O, Kasarda R, Sölkner J (2008) Genetic evaluation for length of productive life in Slovak Pinzgau cattle. Arch Tierz 51, 438-448

M'hamdi N, Aloulou R, Bouallegue M, Brar SK, Hamouda MB (2010) Study of functional longevity of Tunisian Holstein dairy cattle using a Weibull proportional hazard model. Livest Sci 132, 173-176

Mirtaghizadeh SAH (2004) Evaluation of Functional Traits in Different Regions of Dairy Cattle Data in Turkey. J Anim Vet Adv 3, 321-324

Páchová E, Dědková L (2003) [Longevity of Holstein-Frisian cows on farm in Brniště]. Náš Chov 63, 35 [in Czech]

Páchová E, Zavadilová L, Sölkner J (2005) Genetic evaluation of the length of productive life in Holstein cattle in the Czech Republic. Czech J Anim Sci 50, 493-498

Pasman E, Reinhardt F (1999) Genetic evaluation for length of productive life of Holstein cattle in Germany. Interbull Bulletin 21, 55-59

Potočnik K, Jovanovac S, Krsnik J, Gantner V, Štepec M, Raguž N, Gorjanc G, Logar B (2009) Estimation of genetic parameters for longevity in Slovenian dairy cattle populations. In: 44th Croatian and 4th International Symposium on Agriculture, 757-761

Raguž N, Jovanovac S, Gantner V, Mészáros G, Sölkner J (2011) Analysis of factors affecting the length of productive life in Croatian dairy cows. Bulg J Agric Sci 17, 232-240

Řehout V, Polenská E (1990) [Genetic aspects of longevity in cows - the effect of breed]. Živočišná Výroba 35, 193-202 [in Czech]

SAS (2008) SAS ${ }^{\circledR} 9.2$ Enhanced Logging Facilities, SAS Institute Inc., Cary, NC, USA

Sawa A, Bogucki M (2010) Effect of some factors on cow longevity. Arch Tierz 53, 403-414

Schwerin M, Sanftleben H, Grupe S (2003) Genetic predisposition for productive life is associated with functional inactivation of a AP2-binding site in the promoter of the stress protein 70.1-encoding gene in cattle. Arch Tierz 46, 177-185

Sölkner J, Ducrocq V (1999) The survival kit: a tool for analysis of survival data. Interbull Bulletin 21, 3-10

Strapák P, Čanji V, Strapáková E (2008) [Evaluation of longevity in cattle in the Slovak Republic]. Nitra: SUA, 125 p., ISBN 978-80-552-0057-6 [in Slovak]

Strapák P, Juhás P, Strapáková E, Halo M (2010) Relation of the length of productive life and the body conformation traits in Slovak Simmental breed. Arch Tierz 53, 393-402 
Tekerli M, Koçak S (2009) Relationships between production and fertility traits in first lactation and life time performances of Holstein cows under subtropical condition. Arch Tierz 52, 364-370

Terawaki Y, Katsumi T, Ducrocq V (2006) Development of a Survival Model with Piecewise Weibull Baselines for the Analysis of Length of Productive Life of Holstein Cows in Japan. J Dairy Sci 89, 4058-4065

Van der Linde C, Harbers AGF, de Jong G (2007) From functional to productive longevity in the Netherlands. Interbull Bulletin 37, 203-207

Vukasinovic N, Moll J, Künzi N (1997) Analysis of Productive Life in Swiss Brown Cattle. J Dairy Sci 80, 2572-2579

Vukasinovic N, Moll J, Casanova L (2001) Implementation of a Routine Genetic Evaluation for Longevity Based on Survival Analysis Techniques in Dairy Cattle Populations in Switzerland. J Dairy Sci 84, 9, 2073-2080

Yazdi MH, Visscher PM, Ducrocq V, Thompson R (2002) Heritability, Reliability of Genetic Evaluations and Response to Selection in Proportional Hazard Models. J Dairy Sci 85, 1563-1577 